\title{
EFEKTIVITAS PENDIDIKAN GIZI MENGGUNAKAN MEDIA EDUTAINMENT CARD TERHADAP PENINGKATAN PENGETAHUAN TENTANG PEDOMAN GIZI SEIMBANG PADA SISWA SEKOLAH DASAR
}

\section{EFFECTIVENESS OF NUTRITION EDUCATION WITH EDUTAINMENT CARD ON ENHANCEMENT OF KNOWLEDGE ABOUT BALANCE NUTRITION GUIDELINE AT ELEMENTARY SCHOOL}

\author{
Diana Mustikaningsih ${ }^{1}$, J.Supadi $^{2}$, M.Jaelani $^{3}$, Sri Noor Mintarsih ${ }^{4}$, Susi Tursilowati ${ }^{5}$ \\ ${ }^{1}$ Mahasiswa Jurusan Gizi Politeknik Kesehatan Kemenkes Semarang \\ 2,3,4,5 Dosen Jurusan Gizi Politeknik Kesehatan Kemenkes Semarang
}

\begin{abstract}
Background: Indonesia is still faced with a triple burden of nutrition, such as malnutrition, stunting and overnutrition. According to UNICEF, one of the cause nutrition problems is the lack of knowledge about nutrition. The prevention of health problem starts at the early stage, namely the understanding of balance nutrition guideline in school-age children. New method need to be made to make it easier for students to arrest nutrition message, namely in the form of edutainment cards.
\end{abstract}

Objective: To determine the effectiveness of nutrition education by using the edutainment card method on knowledge about balance nutrition guideline in elementary school.

Methods: The type of research is Experimental with pre and post-control group design design. Sampling using random sampling technique to get 30 treatment samples and 30 control samples. Research was in SDN Palebon 02, conducted in Februari 2019. The data collected are sample identity dataand knowledge of balance nutrition guideline. The data was analysed by independent $t$-test with $95 \%$ confidence level.

Results: There was significant difference in knowledge about balance nutrition guideline in the treatment and control groups after intervention with edutainment card method ( $p$ value $=0.001$ ).

Conclusion: Edutainment card as a media for education is effective for increasing nutrition knowledge in children.

Keywords: edutainment, knowledge

\section{ABSTRAK}

Latar Belakang : Indonesia masih dihadapkan kepada beban ganda massalah gizi yaitu kekurangan gizi, stunting, dan kelebihan gizi. Menurut UNICEF, saah satu penyebab masalah gizi adalah kurangnya pengetahuan masyarakat. Penanggulangan masalah kesehatan dimulai dari tingkat bawah yaitu pemahaman tentang Pedoman Gizi Seimbang (PGS) pada anak usia sekolah. Metode baru perlu dibuat untuk memudahkan siswa menangkap pesan gizi yang disampaikan, yaitu berupa edutainment card.

Tujuan : Untuk Mengetahui efektivitas pendidikangizi dengan menggunakan metode edutainment card terhadap peningkatan pengetahuan tentang pendoman gizi seimbang pada Sekolah Dasar.

Metode : Jenis penelitian ini merupakan penelitian Eksperimentaldengan rancangan pre dan post test control group design. Pengambilan sampel dengan menggunakan teknik random sampling untuk mendapatkan 30 sampel perlakuan dan 30 sampel kontrol. Penelitian dilakukan di SDN Palebon 02 pada bulan Februari 2019. Data yang dikumpulkan yaitu data identitas sampel dan pengetahuan tentang gizi seimbang. Uji statistik yang digunakan adalah uji independent $t$-test dengan derajat kepercayaan $95 \%$.

Hasil : Ada pengaruh yang signifikan antara pengetahuan tentang gizi seimbang pada kelompok perlakuan dan kontrol sesudah intervensi dengan metode edutainment card dengan $\mathrm{p}$ value=0,001. Media edutainment card dapat meningkatkan pengetahuan siswa.

Kesimpulan :Pemberian pendidikan gizi tentang pedoman gizi seimbang menggunakan media edutainment card efektif untuk meningkatkan pengetahuan siswa. 


\section{PENDAHULUAN}

Pada saat ini, di Indonesia masih dihadapkan kepada beban ganda masalah gizi yaitu masalah kekurangan gizi (undernutrition), pendek (stunting), kelebihan gizi (overnutrition), termasuk kegemukan ${ }^{1}$. Secara nasional, prevalensi kurus pada anak umur 5-12 tahun adalah $11,2 \%$, terdiri dari $4 \%$ sangat kurus dan 7,2\% kurus. Prevalensi pendek secara nasional pada anak umur 5-12 tahun adalah $30,7 \%$ yang terdiri dari $12,3 \%$ sangat pendek dan $18,4 \%$ pendek. Sedangkan secara nasional, masalah gemuk pada anak umur 5-12 tahun tergolong tinggi yaitu 18,8\% yang terdiri dari 10,8\% gemuk dan $8,8 \%$ sangat gemuk. Salah satunya disebabkan karena rendahnya pengetauan. Rendahnya pengetahuan anak mengenai gizi seimbang dapat dilihat berdasarkan pada beberapa penelitian yang telah dilakukan sebelumnya. Penelitian yang dilakukan di Sekolah Dasar di wilayah kota Semarang menunjukkan bahwa tingkat pengetahuan siswa tentang gizi seimbang dengan kategori baik sebesar $63,6 \%^{2}$. Penelitian lain di Semarang bahkan menunjukkan kalau pengetahuan gizi kategori baik hanya mencapai $9,1 \%$ dari total sampel ${ }^{3}$.

Pendidikan gizi sebaiknya diberikan sedini mungkin, karena anak-anak umunya mempunyai keinginan tinggi untuk mengetahui dan mempelajari sesuatu lebih jauh. Usia anak yang sesuai untuk diberikan pendidikan gizi adalah anak yang berada pada periode 6 - 14 tahun, karena pada usia ini merupakan periode intelektual dimana anak mulai untuk belajar ${ }^{4}$. Penggunaan metode dan media pendidikan Pedoman Gizi seimbang (PGS) yang akan dilakukan dalam penelitian ini bertujuan untuk mempermudah menyampaikan pesan-pesan PGS yang ditujukan pada siswa sekolah dasar. Indera yang paling banyak menyalurkan pengetahuan ke otak adalah indera penglihatan. Sebesar $75 \%$ sampai $87 \%$ dari pengetahuan manusia diperoleh melalui indera penglihatan, $13 \%$ melalui indera dengar dan $12 \%$ lainnya tersalur melalui indera yang lain ${ }^{5}$. Oleh karena itu kami bermaksud membuat media baru yang berfokus pada indera penglihatan sehingga dibuatlah edutainment card.

\section{METODE}

Penelitian ini merupakan penelitian eksperimental dengan rancangan pre test-post test control group design. Pada penelitian ini, subjek yang memenuhi kriteria inklusi dikelompokkan menjadi 2 yaitu kelompok perlakuan (pendidikandengan media edutainment card) dan kelompok kontrol (pendidikandengan metode ceramah).

Penelitian dilakukan di SDN Palebon 02 Pedurungan dengan populasi 60 siswa dan semua berlaku sebagai sampel penelitian. Jumlah subjek penelitian pada kelompok intervensi sebanyak 30 dan pada kelompok kontrol juga 30 siswa. Penelitian dilakukan selama 1 minggu, hari pertama dan ke empat dilakukan penyuluhan. Hari pertama diberikan pre test, hari ke enam diberikan post test.

Kelompok perlakuan dalam penelitian ini diberi pendidikandengan media edutainment card selama 2 kali dalam seminggu pada hari pertama dan hari keempat dengan durasi tiap pertemuan 30 menit. Sedangkan untuk kelompok kontrol diberikan pendidikandengan metode ceramah sebanyak 2 kali pada hari yang sama. Ceramah dilakukan oleh peneliti sendiri sedangkan pendidikandengan metode edutainment card dilakukan oleh peneliti dibantu oleh 5 fasilitator. Sebelum dilakukan intervensi, terlebuh dahulu dilakukan skrining untuk mengetahui apakah sampel pernah terpapar dengan edutaiment card terait gizi seimbang. Data yang dikumpulkan adalah data identidas sampel dan data pengetahuan gizi seimbang yang dilakukan dengan wawancara. Data pengetahuan gizi seimbang diperoleh dengan memberikan pertanyaan sebelum intervensi (pre) dan setelah dilakukan intervensi (post).

Variable dependen yaitu pengetahuan tentang pedoman gizi seimbang, variable independen yaitu penyuluhan dengan media edutainment card. Uji statistic yang dipakai pada penelitian ini adalah uji independent t-test untuk analisis bivariate karena data berdistribusi normal.

\section{HASIL DAN PEMBAHASAN}

Penelitian ini dilaksanakan pada 12 Februari 2019-18 Februari 2019. Lokasi penelitian yang digunakan yaitu SDN Palebon 02 Pedurungan, Semarang. Jumlah subjek penelitian adalah 60 siswa, 30 sampel pada kelompok perlakuan dan 30 sampel pada kelompok kontrol. Subjek penelitian merupakan siswa kelas $\mathrm{V}$.

\section{Jenis Kelamin}

Hasil penelitian menunjukkan jenis kelamin pada kelompok perlakuan sama banyaknya yaitu masing-masing 15 orang $(50,0 \%)$, dan jenis kelamin pada kelompok kontrol menunjukkan 
jumlah laki-laki lebih banyak yaitu 16 anak (53,3\%). Untuk lebih jelasnya data dilihat pada tabel 1 :

Tabel 1. Distribusi frekuensi sampel berdasarkan jenis kelamin

\begin{tabular}{ccccc}
\hline & \multicolumn{5}{c}{ Kelompok } \\
\hline & \multicolumn{2}{c}{ Perlakuan $(\mathrm{n}=30)$} & \multicolumn{2}{c}{ Kontrol (n=30) } \\
\cline { 2 - 5 } & $\mathrm{N}$ & $\%$ & $\mathrm{n}$ & $\%$ \\
\hline Jenis Kelamin & & & & \\
Laki-laki & 15 & 50,0 & 16 & 53,3 \\
Perempuan & 15 & 50,0 & 14 & 46,7 \\
\hline Total & 30 & 100,0 & 30 & 100,0 \\
\hline
\end{tabular}

Umur

Berdasarkan hasil pengumpulan data, diperoleh umur siswa yaitu 11 tahun (100\%), baik di kelompok kontrol maupun di kelompok perlakuan.

Pengetahuan Tentang Gizi Seimbang Sebelum Perlakuan Antara Kelompok Kontrol dan Kelompok Perlakuan

Pada kelompok perlakuan yang memiliki pengetahuan tentang gizi seimbang dengan kategori kurang sebanyak 20 sampel (66,7\%), begitu juga pada kelompok kontrol sebanyak 20 sampel $(66,7 \%)$. Untuk lebih jelasnya dapat dilihat pada tabel 2 .

Tabel 2. Pengetahuan Tentang Gizi Seimbang Sebelum Perlakuan pada Kelompok Kontrol dan Perlakuan

\begin{tabular}{ccccc}
\hline $\begin{array}{c}\text { Lengetahuan Gizi } \\
\text { Sebelum Perlakuan }\end{array}$ & \multicolumn{3}{c}{ Kelompok } \\
& \multicolumn{2}{c}{$\begin{array}{c}\text { Perlakuan } \\
(\mathrm{n}=30)\end{array}$} & \multicolumn{3}{c}{$\begin{array}{c}\text { Kontrol } \\
(\mathrm{n}=30)\end{array}$} \\
\cline { 2 - 5 } & $\mathrm{N}$ & $\%$ & $\mathrm{n}$ & $\%$ \\
\hline Kurang $(<60 \%)$ & 20 & 66,7 & 20 & 66,7 \\
Baik $(\geq 60 \%)$ & 10 & 33,3 & 10 & 33,3 \\
\hline Total & 30 & 100,0 & 30 & 100,0 \\
\hline
\end{tabular}

Pengetahuan Tentang Gizi Seimbang Sesudah Perlakuan Antara Kelompok Kontrol dan Kelompok Perlakuan

Pada kelompok perlakuan yang memiliki pengetahuan tentang gizi seimbang dengan kategori kurang sebanyak 3 sampel (10\%), sedangkan pada kelompok kontrol sebanyak 13 sampel (43,3\%). Untuk lebih jelasnya dapat dilihat pada tabel 3.

Tabel 3. Pengetahuan Tentang Gizi Seimbang Sesudah Perlakuan pada Kelompok Kontrol dan Perlakuan

\begin{tabular}{ccccc}
\hline $\begin{array}{c}\text { Pengetahuan Gizi } \\
\text { Sesudah Perlakuan }\end{array}$ & \multicolumn{4}{c}{ Kelompok } \\
& \multicolumn{2}{c}{$\begin{array}{c}\text { Perlakuan } \\
(\mathrm{n}=30)\end{array}$} & $\mathrm{N}$ & $\begin{array}{c}\text { Kontrol } \\
(\mathrm{n}=30)\end{array}$ \\
\cline { 2 - 5 } & $\mathrm{N}$ & $\mathrm{N}$ & $\%$ \\
\hline Kurang $(<60 \%)$ & 3 & 10,0 & 13 & 43,3 \\
Baik $(\geq 60 \%)$ & 27 & 90,0 & 17 & 56,7 \\
\hline Total & 30 & 100,0 & 30 & 100,0 \\
\hline
\end{tabular}

\section{Paparan terhadap informasi gizi}

Pada kedua kelompok sebagian besar belum terpapar informasi gizi. Pada kelompok perlakuan sebanyak 29 siswa $(96,7 \%)$ belum terpapar, sedangkan pada kelompok kontrol sebanyak 24 siswa (80,0\%). Untuk lebih jelasnya dapat dilihat pada tabel 4 .

Tabel 4. Paparan terhadap Informasi Gizi Seimbang

\begin{tabular}{ccccc}
\hline $\begin{array}{c}\text { Paparan informasi } \\
\text { gizi }\end{array}$ & \multicolumn{5}{c}{ Kelompok } \\
& \multicolumn{2}{c}{$\begin{array}{c}\text { Perlakuan } \\
(\mathrm{n}=30)\end{array}$} & \multicolumn{3}{c}{$\begin{array}{c}\text { Kontrol } \\
(\mathrm{n}=30)\end{array}$} \\
\cline { 2 - 5 } & $\mathrm{n}$ & $\%$ & $\mathrm{n}$ & $\%$ \\
\hline Sudah pernah & 1 & 3,3 & 6 & 20,0 \\
Belum pernah & 29 & 96,7 & 24 & 80,0 \\
\hline Total & 30 & 100,0 & 30 & 100,0 \\
\hline
\end{tabular}

Efektifitas Media Edutainment Card terhadap Pengetahuan Tentang Gizi Seimbang

Hasil uji efektifitas edutainment card terhadap pengetahuan tentang gizi seimbang terdapat pada tabel 5.

Tabel 5. Pengetahuan Sebelum dan Sesudah Perlakuan antara Kelompok Perlakuan dan Kontrol

\begin{tabular}{cccc}
\hline $\begin{array}{c}\text { Pengetahuan gizi } \\
\text { seimbang }\end{array}$ & $\begin{array}{c}\text { Perlakuan (n=30) } \\
\text { Rata-rata } \pm \text { SD }\end{array}$ & $\begin{array}{c}\text { Kelompok } \\
\text { Kontrol (n=30) } \\
\text { Rata-rata } \pm \text { SD }\end{array}$ & $\begin{array}{c}p \text { - } \\
\text { value }\end{array}$ \\
\hline Sebelum Intervensi & $50,17 \pm 14,53$ & $47,50 \pm 17,80$ & 0,528 \\
Post test 1 (1 hari) & $55,17 \pm 17,93$ & $54,67 \pm 17,47$ & 0,913 \\
Post test 2 (1 minggu) & $72,00 \pm 12,57$ & $59,33 \pm 11,94$ & 0,000 \\
\hline BPengetahuan(pre & $21,83 \pm 11,78$ & $11,83 \pm 11,33$ & 0,001 \\
test-post test2) & & 11,833 & \\
\hline
\end{tabular}

Dari tabel 5 dapat diketahui bahwa ratarata skor pengetahuan gizi seimbang sebelum intervensi pada kelompok perlakuan adalah $50,17 \pm 14,53$ sedangkan rata-rata skor pengetahuan pada kelompok kontrol yaitu $47,50 \pm 17,80$. Sebelum dilakukan uji statistik, data terlebih dahulu diuji kenormalannya. Hasil uji normalitas data menunjukkan hasil bahwa data berdistribusi normal sehingga uji statistic yang digunakan adalah independent t-test. Hasil uji independent t-test diperoleh hasil bahwa tidak terdapat perbedaan pengetahuan gizi seimbang sebelum intervensi pada kedua kelompok dibuktikan dengan nilai $p=0,528(p \geq 0,05)$. Pada hari pertama intervensi dilakukan post test pertama dan diperoleh hasil bahwa kenaikan pada kelompok kontrol lebih tinggi namun setelah dilakukan selama seminggu keadaan berbalik, nilai kelompok intervensi meningkat lebih besar sebesar 21,83 sedangkan pada kelompok kontrol 11,83.

Berdasarkan penelitian lain peningkatan pada post tes 1 tidak efektif karena pembelajaran 
dan komunkasi yang kurang efisien, karena manusia bersifat pelupa sehingga diperlukan pembelajaran yang berulang dan ditambahkannya media untuk menghasilkan cara belajar yang efektif dalam waktu yang singkat tetapi juga diterima, terekam lebih lama dan tinggal di dalam ingatan ${ }^{6}$.

Rata-rata pengetahuan gizi seimbang setelah intervensi pada kelompok perlakuan adalah $72,00 \pm 12,57$ sedangkan rata-rata pengetahuan setelah intervensi pada kelompok kontrol yaitu $59,33 \pm 11,94$. Hasil uji independent t-test diperoleh hasil bahwa ada perbedaan yang bermakna pada kedua kelompok, hal ini dibuktikan nilai $p=0,000$ $(p<0,05)$.

Rata-rata perubahan pengetahuan gizi seimbang sebelum dan sesudah intervensi pada kelompok perlakuan adalah 21,83 , sedangkan pada kelompok kontrol adalah 11,83. Dari kedua hasil tersebut menunjukkan adanya peningkatan pengetahuan setelah dilakukan intervensi dan hasil uji statistik $t$-test diperoleh nilai $p=0,001 \quad(p<0,05)$ menunjukkan bahwa ada perbedaan bermakna pada perubahan pengetahuan gizi seimbang pada kelompok perlakuan dan kontrol.

\section{PEMBAHASAN}

Media bergambar yang dipergunakan dalam penelitian ini ternyata memberikan dampak yang positif terhadap peningkatan pengetahuan terhadap pengatahuan siswa ${ }^{7}$. Media yang terdiri dari gambar-gambar dan warna yang mencolok memberikan daya tarik siswa sebagai responden untuk melihat dan memperhatikan materi yang diberikan oleh peneliti, penggunaan gambar yang familiar dengan kondisi mereka sehari-hari merupakan salahsatu nilai tambah dalam penggunaan media bergambar dalam peningkatan pengetahuan tentang ksehatan ${ }^{8}$. Hal ini juga terjadi pada penelitian ini, siswa antusias menggunakan media tersebut.

Kegiatan pembelajaran dengan menggunakan media edutainment dapat membangkitkan semangat belajar siswa dan merangsang imajinasi seperti yang dikemukakan peneliti sebelumnya ${ }^{9}$, ketika dilaksanakan intervensi siswa juga sangat antusias. Sebagaimana hasil penelitian yang menyatakan bahwa media yang digunakan dalam proses pembelajaran menjadi lebih menarik perhatian sehingga dapat mudah dipahami dan menyebabkan sasaran tidak menjadi cepat bosan ${ }^{10}$. Pemanfaatan sumber belajar berupa media pembelajaran, dapat meningkatkan keinginan dan minat baru, membangkitkan motivasi dan merangsang kegiatan belajar dan bahkan membawa pengaruh psikologis terhadap siswa. Penggunaan media pembelajaran sangat membantu keefektifan proses pembelajaran dan penyampaian pesan.

Disamping membangkitkan motivasi dan minat siswa, media pembelajaran juga dapat membantu siswa meningkatkan pemahaman, menyajikan data dengan menarik dan terpercaya serta mendapatkan informasi ${ }^{11}$. Agar media yang digunakan lebih efektif, media visual sebaiknya melibatkan interaksi siswa sebagai penyampai informasi ${ }^{12}$.Pada saat dilaksanakan penelitian, siswa memang sangat tertarik dengan media permainan tersebut dan terbukti dari nilai statistik bahwa media tersebut efektif untuk membantu menangkap materi yang disampaikan, hal ini karena masa sekolah dasar merupakan masa bermain sehingga siswa mudah menangkap informasi yang disampaikan. Permainan bagi anak adalah apa yang mereka lakukan sepanjang hari, bermain adalah kehidupan dan kehidupan adalah bermain. Anakanak tidak membedakan antara bermain, belajar dan bekerja. Anak-anak adalah pemain alami, mereka menikmati bermain dan dapat berkonsentrasi dalam waktu yang lama untuk sebuah ketrampilan ${ }^{13}$. Tahapan belajar melalui proses bermain adalah ketertarikan, kemampuan membedakan, untuk menilai, menganalisis dan mengambil intisari. Dalam hal ini, ketika siswa masih tertarik pada media, maka dapat dengan mudah mengambil intisari dari pesan yang disampaikan ${ }^{14}$.

Hasil peningkatan pengetahuan dari kedua kelompok menunjukkan bawah peningkatan pengetahuan dengan metode edutainment card lebih tinggi daripada metode ceramah, hal ini terjadi karena metode edutainment memiliki kelebihan menarik dan menjadikan materi lebih mudah diterima. Sedangkan kelemahan dari metode ceramah yaitu siswa pasif dan mudah bosan. Permainan berfungsi sebagai sublimasi artinya suatu pelarian dari suatu perasaan tertekan yang berlebihan menuju hal-hal positif, karena anak akan merasa bosan bila duduk seharian di dalam kelas seperti berlangsungnya proses ceramah dimana siswa hanya duduk mendengarkan materi yang disampaikan ${ }^{15}$.

Peserta didik yang belajar dengan suasana monoton, baik dari segi cara, lingkungan, maupun sumber belajarnya akan merasa bosan dan jenuh. Jika tiap hari dihadapkan pada rutinitas yang sama maka proses belajar mereka hanya sebuah keterpaksaan karena takut terkena sanksi. Maka dari itu sebaiknya ada kombinasi antara ceramah dengan media sehingga hasil belajar lebih efektif dan siswa tidak bosan karena suasana menghibur dan menyenangkan sangat dibutuhkan oleh peserta didik dalam belajar. Peserta didik yang belajar pada suasana menyenangkan akan memiliki antusiasme 
tersendiri ${ }^{16}$. Pesan akan mudah dipahami jika mengandung beberapa prinsip yaitu diantaranya : 1) memiliki daya tarik, 2) sesuai dengan kebutuhan siswa, 3) dalam lingkup area of experience dan 4) keaktifan peserta didik dalam proses pembelajaran ${ }^{17}$. Hal ini terlihat pada proses pembelajaran menggunakan media edutainment card. Siswa menarik dan aktif dalam penyampaian informasi tersebut.

Media kartu berisi media ajar berupa gambar, keterangan gambar, pertanyaan sesuai dengan materi yang disajikan juga mengandung unsur belajar sebagai unsur pokok dan permainan sebagai unsur hiburan dan dapat meningkatkan hasil belajar siswa ${ }^{18}$. Hal ini sesuai hasil penelitian bahwa hasil pengetahuan meningkat sebesar 21,83 dan secara statistik meningkat signifikan. Hal tersebut di dukung pula dengan hasil penelitian yang menemukan bahwa pendidikan kesehatan berpengaruh pada peningkatan pengetahuan ${ }^{19}$. Hasil penelitian Rufiati (2011), Hamida (2012) dan Zulaekah (2012) juga menemukan bahwa penggunaan media pendidikandapat mempengaruhi peningkatan pengetahuan ${ }^{20}$.

Faktor yang lain yaitu akses terhadap informasi, berdasarkan sumber dan frekuensi didapatkannya informasi tentang gizi perlu untuk diketahui karena akan berpengaruh terhadap tingkat pengetahuan anak terkait informasi gizi, terutama informasi mengenai pilar dalam PGS. Selain itu, daya terima terhadap media yang diberikan juga dapat mempengaruhi sasaran dalam memahami pesan/materi, dimana variable ini tidak diteliti $^{21}$. Dan dari kedua kelompok hanya 23,3\% siswa yang sudah terpapar informasi tersebut namun tidak mampu menjelaskan secara tepat informasi yang didapatkannya padahal penelitian lain menyebutkan bahwa ada pengaruh antara sumber informasi dengan pengetahuan seseorang ${ }^{22}$. Sebagian memperoleh informasi tersebut dari media televisi.

Berdasarkan hasil pretest dan posttest, siswa kesulitan menjawab soal nomor $2(36,7 \%)$ yaitu soal mengenai syarat makanan yang baik untuk memenuhi kebutuhan gizi dan soal nomor 20 $(46,7 \%)$ mengenai pesan kesepuluh PGS "Lakukan aktifitas fisik yang cukup dan pertahankan berat badan normal". Siswa masih kurang mengerti mengenai kedua hal tersebut. Sedangkan yang paling banyak dijawab benar adalah soal nomor 3 $(83,3 \%)$ mengenai karbohidrat sebagai sumber energy, nomor 1 (80\%) pengertian dari pedoman gizi seimbang dan nomor 18 (80\%) mengenai efek dari kurangnya mengkonsumsi makanan bergizi.

Perilaku seseorang akan lebih baik dan dapat bertahan lebih lama apabila didasari oleh tingkat pengetahuan dan kesadaran yang baik.
Seseorang yang mempunyai pengetahuan yang baik terhadap sesuatu hal diharapkan akan mempunyai sikap yang baik juga. Pengetahuan gizi bisa diperoleh dari pendidikan formal maupun informal $^{23}$. Pendidikan formal dapat diperoleh dari sekolah dengan diadakannya edukasi gizi. Edukasi gizi adalah proses belajar dalam bidang gizi sehingga dapat mempengaruhi pengetahuan, sikap dan perilaku mengenai gizi yang lebih baik ${ }^{9}$.

\section{KESIMPULAN}

Pemberian pendidikan gizi tentang pedoman gizi seimbang menggunakan media edutainment card efektif untuk meningkatkan pengetahuan siswa.

\section{SARAN}

Media edutainment dapat digunakan sebagai media pendidikan untuk melengkapi cara pembelajaran yang sudah ada, khususnya untuk pendidikan tentang gizi terhadap anak sekolah dasar.

\section{DAFTAR PUSTAKA}

1. Kemenkes. Riset Kesehatan Dasar. Jakarta: Badan Penelitian dan Pengembangan; 2013.

2. Redyastuti E, Wijaningsih W, Jaelani. Pengetahuan dan Sikap Tentang Gizi Seimbang pada Siswa Sekolah Dasar dengan Pemberian Edukasi Gizi Menggunakan Media Komik. Jurnal Riset Gizi 5,2 (2017), 27-31

3. Rahayu M, Ambarwati R, Noor S. Efektivitas Edukasi Dengan Media Audiovisual terhadap Pengetahuan dan Sikap tentang Gizi Seimbang. 2017.

4. Wulandari. Peningkatan Pengetahuan Gizi pada Anak Sekolah dengan Metode Ceramah dan Role Play. Skripsi. 2007.

5. Azhar A. Media Pembelajaran. Jakarta: PT. Rajagrafindo Persada; 2006.

6. Demitri, dkk. Pengaruh Pendidikan Gizi Tentang Pola Makan Seimbang Melalui Game Puzzle Terhadap Peningkatan Pengetahuan Anak SDN 067690 Kota Medan. Naskah Publikasi; 2016.

7. Gani A. Pedoman Strategi KIE Keluarga Sadar Gizi (KADARZI). Jakarta: Direktorat Jenderal Bina Kesehatan Masyarakat; 2014.

8. Hamdalah A. Efektivitas Media Cerita Bergambar Dan Ular Tangga Dalam Pendidikan Kesehatan Gigi dan Mulut Siswa SDN 2 Patrang Kabupaten Jember. J Unnes. 2013; Vol.1, No.:118-123.

9. Mubarak. Promosi Kesehatan Sebuah Pengamatan Proses Belajar Mengajar Dalam 
Pendidikan. Yogyakarta: Graha IImu; 2007.

10. Hamida K dkk. PendidikanGizi dengan Media Komik Untuk Meningkatkan Pengetahuan Tentang Keamanan Makanan Jajanan. J Kesehat Masy. 2012;Vol.8 (1):67-73.

11. Nur A. Pengembangan Media Komik Bergambar Materi Sistem Saraf Untuk Pembelajaran yang Menggunakan Strategi PQ4R. J Innov Sci Educ. 2012;JISE 1 (1):19-27.

12. Arsyad, A. Media Pembelajaran. Jakarta: PT Rajagrafindo Persada ; 2016.

13. Wira S. Membangun Kebugaran Jasmani Dan Kecerdasan Melalui Bermain. Jakarta: Dirjen Dikti, Direktorat Ketenagaan; 2006.

14. Lee et all. A Triangulation Method for The Sequential Mapping of Point From N-space to two-space. IEEE Trans Comput. 1977:26:288292.

15. Kemendikbud. Modul Pendidikan Dan Latihan Profesi Guru. Kebijakan. Jakarta: Kemendikbud; 2015.

16. Suryani N dkk. Media Pembelajaran Inovatif Dan Pengembangannya. (Pipih Latifah, ed.). Bandung: PT Remaja Rosdakarya; 2018.
17. Anitah, S. Media Pembelajaran. Surakarta : Yuma Pustaka ; 2010.

18. Hamdani H. Pegembangan Sistem Pendidikan Di Indonesia. Bandung: Pustaka Setia; 2013.

19. Saludeen dkk. Effect of Health Education on Cigarette Smoking Habits of Young Doults in Tertiaty Institutions In A Northerm Nigerian State. Heal Sci J. 2013; Volume 5(Issue I).

20. Rufiati AM dkk. Pengaruh Metode Permainan Find Your Mate terhadap Peningkatan Pengetahuan Kader Posyandu. J Kesehat Masy. 2011;KESMAS 6 :113-119.

21. Notoatmodjo. Metodologi Penelitian Kesehatan. Jakarta: Rineka Cipta; 2012.

22. Gustina, E, \& Djanah, S.N. Sumber Informasi dan Pengetahuan tentang Menstrual Hygiene pada Remaja Putri, Jurnal Kemas. 2015. 10 (2) 147-152

23. Kusumarani, A., Noviardhi, A., Susiloretni, K. A., \& Setiadi, Y. (2018). PENGARUH MEDIA KOMIK TERHADAP PENGETAHUAN DAN SIKAP TENTANG SAYUR DAN BUAH DI SD AISYIYAH DAN SDN KALICILIK 2 DEMAK. Jurnal Riset Gizi, 6(2), 46-50. 